УДК 347.4

DOI https://doi.org/10.32837/pyuv.v0i2(31).560

\author{
П. Д. Гуйван \\ orcid.org/0000-0003-3058-4767 \\ кандидат юридичних наук, заслужений юрист України, \\ професор \\ Полтавського інституту бізнесу \\ Міжнародного науково-технічного університету \\ імені академіка Юрія Бугая
}

\title{
ПРАВОВІ ПЕРЕДУМОВИ ОБМЕЖЕННЯ ПРАВА НА ВИСЛОВЛЮВАННЯ ВЛАСНИХ ДУМОК
}

Вільне та безперешкодне вираження своїх переконань і поглядів та свобода масової інформації є важливою запорукою розвитку демократії та дотримання принципу верховенства права, істотним фактором, що сприяє побудові правової держави. Свобода слова є по суті ключовим чинником, який забезпечує розвиток і прояв людської індивідуальності, утвердження самобутності й унікальності кожної особистості. Гарантування цієї свободи є найважливішою задачею правого регулювання в будь-якій державі, включаючи й українську. Свобода за політичним змістом має вищу природну нормативність, у силу чого гарантування свободи становить основну функцію конституції як правового джерела, що охороняє інтереси громадянського суспільства. Суспільство зацікавлене в досягненні ідеологічної багатоманітності отримуваної інформації, а це означає вільне здійснення в соціумі різних політичних і гуманітарних поглядів, вільне існування думок, ідей, можливість без перешкод пропагувати свої погляди, позиції за допомогою засобів масової інформації, а також привселюдно захищати свої ідеологічні принципи [1, с. 294, 296].

Однією з головних світових правничих інституцій, покликаних здійснювати правове регулювання в цій сфері, є Європейський суд з прав людини. Він за час своєї діяльності напрацював усталені демократичні підходи, які дозволяють виважено вирішувати окремі колізії, що неодмінно виникають при реалізації правовідносин у коментованій царині. За позицією ЄСПЛ приписи ст. 10 Конвенції про захист прав людини й основоположних свобод слід розуміти таким чином, що свобода вираження думки є однією з основних підвалин демократичного суспільства, головною умовою його розвитку та підставою самореалізації кожної його члена. Безумовно, держави користуються певною свободою розсуду для визначення того, чи є необхідним і якою мірою втручання у здійснення свободи вираження думки, особливо в тому, що стосується вибору методів - розумних і відповідних, використовуваних властями для забезпечення мирного розвитку законної діяльності. Проте ця свобода розсуду нерозривно пов'язана 3 контро- лем Суду, який повинен упевнитися, що втручання відповідало законній переслідуваній меті, враховуючи видатне місце свободи вираження думки у світовому демократичному поступі [2, п. 101]. На жаль, у національному правовому середовищі на завжди органи влади та суди враховують зазначені правові підходи, нехтуючи правами людини на свободу вираження та застосовуючи різноманітні види економічного та політичного примусу людей, котрі змушені висловлювати погляди, які не відповідають їхнім думкам і переконанням. Тож досліджуване питання особливо актуальне у світлі тривалого порушення свободи думки, причому на всіх рівнях суспільного життя, що $€$ надзвичайно великою бідою, яка призводить до деформації людини, суспільства, держави та їхніх інституцій [3, с. 50].

Питання стосовно регламентації відносин у сфері вираження особистих поглядів і проблематика їхнього приведення до рівня світових демократичних вимог розглядалися такими науковцями, як Н. Виноградова, В. Павловський, І. Бачило, Г. Красноступ, Д. Літтл, М. Швець, О. Олійник, А. Токарська, В. Погорілко, та ін. Ними були досліджені важливі аспекти повноважень особи щодо можливості висловлювати власні погляди у засобах масової інформації та інших публічних майданчиках. Також аналізувалося дотримання визначених законом засад обмеження цього права громадян. Водночас практично не вивчалися питання врахування критеріїв пропорційності втручання владних структур у свободу вираження думок, що на практиці тягне свавілля та незаконне обмеження прав людини у коментованій сфері. Потребують подальшого розвитку концептуальні напрацювання критеріїв належності обгрунтування мотивації прийнятого рішення, з урахуванням обгрунтованості врахування чи відхилення тих чи інших фактичних обставин та аргументів. Вивчення вказаних аспектів інформаційних відносин є метою цієї праці.

Відповідно до усталеної практики Європейського суду з прав людини свобода вираження поглядів є одним із засадничих положень демократичного розвитку держави та соціуму [4, п. 101]. 
Основоположні принципи стосовно свободи вираження набувають особливого значення, коли йдеться про пресу, провідну роль якої у правовій державі не слід забувати і применшувати. Хоча преса не повинна переступати межі, встановлені в інтересах національної безпеки, захисту громадян або для підтримання авторитету правосуддя, проте на ній лежить обов'язок повідомляти відомості й ідеї з питань, що становлять суспільний інтерес. Якби було інакше, то преса не змогла б здійснювати свою основну роль «громадського спостерігача» [5, п. 59]. Отже, свобода вираження поглядів є одним із важливих чинників сучасного суспільства, зокрема це стосується свободи політичних і громадських дебатів. Це набуває особливого значення для формування пресою, яка має легітимний інтерес у повідомленні та висвітленні інформації, уваги громадськості до чеснот і недоліків уряду, включаючи можливу його протизаконну діяльність.

Але право на свободу вираження не є абсолютним. Ст. 10 Конвенції у своїй першій частині гарантує свободу вираження поглядів, у другій визначає випадки, коли така свобода може бути обмежена. Обмеження права на вільне висловлювання власних поглядів і позицій не є порушенням Конвенції, якщо ці обмеження були встановлені задля досягнення однієї з цілей, зазначених у п. 2 ст. 10. Ст. 18 Конвенції вказує, що обмеження, дозволені щодо зазначених прав і свобод, не застосовуються для інших цілей, ніж ті, для яких вони встановлені. Отже, дуже важливо, щоб застосування права на свободу вираження не порушувало охоронювані інтереси держави та суспільства і права інших людей, адже можливість гарантування вільного самовираження тісно пов'язана із захистом демократії, а вона, у свою чергу, мусить забезпечувати повагу до прав інших людей. Тож нормативне закріплення обмеження права на свободу вираження поглядів покликане встановити рівновагу між правами осіб, а також між правом особи та інтересами демократичного суспільства у разі, коли між ними може виникнути конфлікт [6, с. 12].

Способи обмеження свободи права на самовираження можуть бути різними, від заборони на вчинення певних виступів чи публікацій до притягнення винної особи до адміністративної та навіть кримінальної відповідальності. При визначенні відповідності заходу втручання у свободу слід мати на увазі, що гарантії, які держава мусить надавати пресі, мають особливе значення. Необхідність будь-якого втручання у здійснення свободи вираження повинна бути переконливим чином встановлена. Звичайно, насамперед національні органи влади повинні оцінити, чи існує «невідкладна суспільна потреба», здатна виправдати це втручання, у здійсненні якого вони корис- туються певною свободою розсуду. Однак у цьому разі свобода розсуду держави зіштовхується з інтересами демократичного суспільства в забезпеченні та підтримці свободи преси. Тож у завдання Європейського суду з прав людини входить не підміна національних судів, а контроль за відповідністю ст. 10 тих рішень, які вони винесли, здійснюючи своє право на розсуд. Для цього суд повинен розглянути оскаржуване втручання у світлі всієї справи, щоб перевірити, чи були доводи, наведені національними властями в його виправдання, достатніми і відповідними критеріям п. 2 ст. 10 Конвенції [7, п. 47].

Однією 3 найбільш серйозних i вразливих санкцій за порушення суттєвих державних або суспільних інтересів зловживаннями у сфері публічного поширення власних думок є судова заборона оприлюднення тієї чи іншої інформації. Дійсно, ст. 10 Конвенції своїм текстом не забороняє накладення на публікацію попередніх судових заборон як таких. Таким чином реалізується положення цієї норми стосовно призначення легітимного втручання, зокрема запобігання правопорушенням. Водночас ризики, що випливають із попередніх судових заборон, вимагають ретельного дослідження з боку Європейського Суду. Особливо це може бути застосовано там, де йдеться про пресу, оскільки новини - товар з обмеженим періодом часу, і відстрочка публікації, навіть на короткий термін, цілком може позбавити відомості всієї цінності та інтересу. Показовою в цьому відношенні є справа «Обсервер і Гардіан проти Сполученого Королівства», яка розглядалася ЄСПЛ [5]. За фабулою цієї справи британські газети опублікували статтю колишнього працівника спецслужб, у якій він, використовуючи раніше оприлюднені матеріали, висловлював жорстку критику дій державних компетентних органів. За рішенням владних органів публікація була знята й арештована.

При розгляді заяв скаржників ЄСПЛ встановив, що затяжний ефект заборон, накладення попереднього обмеження подальшої публікації питань, що викликають легітимний інтерес громадськості, був втручанням у свободу заявників із широкими негативними наслідками. Комісія повинна перевірити, чи було це втручання виправданим відповідно до ч. 2 ст. 10. Для того, аби справедливо та чесно вирішити цей спір, слід з'ясувати, чи оскаржуване втручання відповідало нагальній соціальній потребі та було пропорційним досягненню законної мети. Ключовим аспектом, який з'ясовував і вивчав Суд, було дослідження втручання на предмет його відповідності нагальній соціальній потребі. Питання не просте, бо в розглядуваній ситуації було виявлене істотне протистояння двох значних соціальних цінностей - публічного права на вільне поширення особистих ідей і переконань та інтересу щодо під- 
тримання авторитету і безсторонності суду. 3 великими труднощами (6 - «за», 5 - «проти») Суд дійшов висновку про пріоритет права особи на свободу слова, а відповідне втручання держави було визнане незаконним (п. 73-77).

Позаяк конвенційна ст. 10 захищає не лише суть ідей і висловленої інформації, але також ту форму, в якій вони передаються, при кожному розгляді питання про застосування обмежень слід розглядати комплект обставин у їхньому співвідношенні. Має бути з'ясовано, чи є причини, висунуті національним органом, щоб виправдати втручання, релевантними та достатніми, чи були застосовані засоби пропорційними законній меті, яка переслідувалася. Для застосування обмежень необхідно переконатися у тому, що національні органи влади застосовували стандарти, які відповідали принципам, закладеним у ст. 10 Конвенції, а також у тому, що вони грунтувалися на прийнятній оцінці відповідних фактів. Оцінка має враховувати спосіб публічного вираження думок і переконань, їхній зміст, контекст, у якому була проведена трансляція та мета програми [8, п. 31]. За усталеною правозастосовною практикою ЄСПЛ напрацював критерії, згідно з якими може визначатися обґрунтованість втручання у свободу вираження поглядів. За загальним правилом воно є допустимим, якщо механізм подібного обмеження права прямо встановлений законом і втручання $є$ необхідним у демократичному суспільстві.

Перелік інтересів суспільства, держави та конкретної особи, що можуть порушуватися у зв' язку зі зловживанням правом на самовираження, встановлений у ч. 2 конвенційної ст. 10. Таким чином втручання у право особи на свободу вираження поглядів становитиме порушення ст. 10 Конвенції, якщо воно не підпадатиме під один із винятків, встановлених п. 2 ст. 10 Конвенції. Але лише поверхового віднесення категорії до тих, охорона яких може відбуватися за правилом ч. 2 цієї норми, не означає легітимності обмежень із боку влади. Втручання державних органів повинно не лише відбуватися на законних підставах, а i передбачати відповідний процесуальний інструментарій, який чітко визначає межі необхідної поведінки як суб'єкта права на вираження, так і органів правопорядку. Без такого юридичного механізму в суспільстві пануватиме суб'єктивізм і свавілля. Основоположною ідеєю запровадження цього правила якраз і є мета унеможливлення свавільного та незаконного втручання у здійснення свободи вираження поглядів. Слово «закон» у формулюванні «передбачено законом» охоплює не лише статути, а і неписане право. Більше того, навіть чітко регламентовані законодавчо правила можуть бути визнані незастосовуваними, якщо вони не відповідають встановленим міжнародно-правовим засадам. Саме з метою запобігання несправедливим законам ЄСПЛ вказує, що закон має бути загальнодоступним для того, щоб громадянин знав, що за певних обставин застосовується саме цей закон. Правова норма не може вважатися законною, доки вона не сформульована достатньо чітко, щоб громадянин був спроможний регулювати свою поведінку, а також міг у разі надання йому кваліфікованої консультації розумно передбачити наслідки, до яких призведе його певна дія [9, п. 47, 49].

Отже, при розгляді спору щодо законності втручання у право на висловлення особистих переконань спочатку необхідно розглянути питання, чи було втручання у цій справі «встановлене законом». Коли буде визнано, що втручання не $\epsilon$ законним, цього достатньо, щоб визнати дії держави-відповідача неправомірними. Натомість, коли для обмеження існують належні юридичні підстави, це ще не означає, що втручання держави в особі її органів контролю або суду було правомірним. Підлягають окремому з'ясуванню також інші чинники, які визначають подібний результат: чи переслідувало обмеження ціль, що є легітимною відповідно до п. 2 ст. 10 , та чи було воно "необхідним у демократичному суспільстві» задля досягнення зазначеної мети [9].

Iз викладеного можемо зробити певні висновки. Свобода слова є визначальним чинником, який впливає на формування активного громадянського суспільства. Для практичної реалізації цієї свободи неодмінною передумовою є доступ до засобів масової інформації, що дозволить особі, зокрема через критику посадових осіб чи їхньої політики, формувати суспільні погляди та громадську думку. Але важливо не припуститися порушень приватних прав інших осіб чи інтересів держави. Питання, пов'язані з колізією зазначених суспільних інтересів, не такі вже й прості. Вони потребують ретельного з'ясування, в т. ч. і на рівні судового розгляду, співмірності права на свободу слова 3 державними обмеженнями, що можуть застосовуватися. Мають використовуватися критерії, розроблені та широко застосовувані міжнародною спільнотою: обмеження повинно бути передбачене законом, відповідати принципам передбачуваності та прозорості, переслідувати одну із легітимних цілей, бути прийнятним i необхідним у суспільстві.

\section{Jimepamypa}

1. Слинько Т.М. Конституційно-правові гарантії свободи слова в Україні. Правова доктрина - основа формування правової систели держави : матеріали Міжнар. наук.-практ. конф., присвяч. 20-річчю НАПрН України (м. Харків, 20-21 листоп. 2013 р.). Харків : Право, 2013. С. 294-297.

2. Рішення ЄСПЛ від 23 вересня 1998 р. у справі «Стіл та інші проти Сполученого Королівства» (Steel and Others v. the United Kingdom), заяви 
№ 67/1997/851/1058. URL: https://hudoc.echr.coe.int/ rus\#\{"itemid":["001-58240"]\}.

3. Кушніренко О.Г. Свобода слова як конституційна цінність. Вісник Харківського національного університету імені В.Н. Каразіна. Серія «Право». 2013. № 15 . C. $49-52$.

4. Рішення ЄСПЛ від 10 грудня 2007 р. у справі «Столл проти Швейцарії» (Stoll v. Switzerland), заява № 69698/01. URL: https://www.5rb.com/case/stoll-vswitzerland/.

5. Рішення ЄСПЛ від 26 листопада 1991 р. у справі «Обсервер» i «Гардіан» проти Великої Британі (Observer and Guardian v. the United Kingdom), заява № 13585/88. URL: http://europeancourt.ru/uploads/ ECHR_Observer_and_Guardian_v_The_United Kingdom $26 \quad 11$ 19 91 .p $\bar{d} f$.

6. Зайцев Ю. Утаємничення інформації - табу для журналіста? (Європейський аспект). Законодавчий бюлетень. 2001. № 2. С. 12.

7. Рішення ЄСПЛ від 29 серпня 1997 р. у справі "Ворм проти Австрії» (Worm v. Austria), заява № 22714/93. URL: https://hudoc.echr.coe.int/ fre\#\{"itemid":["001-58087"]\}.

8. Рішення ЄСПЛ від 23 вересня 1994 р. у справі «Джерсільд проти Данії» (Jersild v. Denmark), заява № 15890/89. URL: https://www.hr-dp.org/ files / $2013 / 09 / 09 /$ CASE_OF_JERSILD_v. DENMARK .pdf.

9. Рішення ЄСПЛ від 26 квітня 1979 р. у справі «SundayTimes v. the United Kingdom», заява №6538/74 URL: https://cedem.org.ua/library/sprava-sandi-tajmsproty-spoluchenogo-korolivstva-2/.

\section{Анотація}

Гуйван П. Д. Правові передумови обмеження права на висловлювання власних думок. - Стаття.

Стаття присвячена дослідженню актуального питання щодо правового регулювання підстав і порядку державного втручання у право особи на вираження своïx думок, поглядів і переконань. Підкреслюється, що відповідне право особи не є абсолютним, але його обмеження припускається виключно у випадках, коли користування ним порушує права інших людей, створює небезпеку для охоронюваних законом державних чи громадських інтересів. У роботі аналізується практика однієї з головних світових правничих інституцій, покликаних здійснювати правове регулювання в цій сфері - Європейського суду з прав людини. Він за час своєї діяльності напрацював усталені демократичні підходи, які дозволяють виважено вирішувати окремі колізії, що неодмінно виникають при реалізації правовідносин у коментованій царині. За позицією ЄСПЛ, попри те, що держава користується певною свободою розсуду для визначення того, чи є необхідним і якою мірою втручання у здійснення свободи вираження думки, ця діяльність мусить відбуватися з урахуванням визначального значення свободи слова у суспільстві. Встановлено, що в національному правовому середовищі на завжди органи влади та суди враховують європейські правові підходи та нехтують правами людини на свободу вираження.

Окремо в роботі розглянуті основоположні принципи стосовно свободи вираження, що набувають значення, коли йдеться про пресу, провідну роль якої у правовій державі не слід забувати і применшувати. Вивчені напрацьовані усталеною правозастосовною практикою ЄСПЛ критерії, згідно з якими може визначатися об-
Ірунтованість втручання у свободу вираження поглядів. За загальним правилом воно є допустимим, якщо механізм подібного обмеження права прямо встановлений законом, і втручання є необхідним у демократичному суспільстві. Оцінені деякі способи обмежень свободи преси, наголошується, що за їхнього запровадження мусить бути з'ясоване питання, чи існує «невідкладна суспільна потреба», здатна виправдати це втручання. Питання не просте, бо в кожній окремій ситуації існує протистояння двох значних соціальних цінностей - публічного права на вільне поширення особистих ідей і переконань та держави або приватних осіб. Вирішувати його слід з урахуванням суспільних пріоритетів, застосовуючи принципи справедливості та напрацювання світової демократичної практики.

Ключові слова: свобода слова, легітимність втручання, вираження поглядів.

\section{Summary}

Guyvan P. D. Legal preconditions for restricting the right to express one's opinions. - Article.

This article is devoted to the research of the topical issue of legal regulation of the grounds and procedure for state intervention in the right of a person to express their opinions, views and beliefs. It is emphasized that the relevant right of a person is not absolute. But its restriction is allowed only in cases where its use violates the rights of others, creates a danger to the legally protected state or public interests. The paper analyzes the practice of one of the world's major legal institutions designed to regulate in this area, the European Court of Human Rights. During his career, he developed well-established democratic approaches that allow for a balanced resolution of individual conflicts that inevitably arise in the implementation of legal relations in the commented area. According to the ECtHR, despite the fact that the state enjoys a certain discretion to determine whether and to what extent, interference with the exercise of freedom of expression, this activity must take into account the crucial importance of freedom of speech in society. It has been established that in the national legal environment, the authorities and courts take into account European legal approaches and neglect human rights to freedom of expression.

Separately, the paper examines the basic principles of freedom of expression, which are important when it comes to the press, whose leading role in the rule of law should not be forgotten and underestimated. The criteria developed by the established law enforcement practice of the European Court of Human Rights, according to which the validity of interference with freedom of expression can be determined, have been studied. As a general rule, it is permissible if the mechanism of such a restriction of law is directly established by law and interference is necessary in a democratic society. Some ways of restricting the freedom of the press have been assessed, and it is emphasized that their introduction must clarify whether there is an "urgent public need" that can justify this intervention. The question is not simple, because in each situation there is a confrontation of two significant social values - the public right to free dissemination of personal ideas and beliefs and the state or individuals. It should be solved taking into account social priorities, applying the principles of justice and the development of world democratic practice.

Key words: freedom of speech, legitimacy of intervention, expression of views. 